\title{
Allergen-induced airway responses
}

\author{
Gail M. Gauvreau, Amani I. El-Gammal and Paul M. O’Byrne
}

\section{Affiliation:}

Firestone Institute for Respiratory Health and the Department of Medicine, McMaster University, Hamilton, ON, Canada.

\section{Correspondence:}

Paul O'Byrne, McMaster University, HSC 3W10, 1280 Main St West, Hamilton, ON L8S 4K1, Canada.

E-mail: obyrneplamcmaster.ca

ABSTRACT Environmental allergens are an important cause of asthma and can contribute to loss of asthma control and exacerbations. Allergen inhalation challenge has been a useful clinical model to examine the mechanisms of allergen-induced airway responses and inflammation. Allergen bronchoconstrictor responses are the early response, which reaches a maximum within 30 min and resolves by $1-3 \mathrm{~h}$, and late responses, when bronchoconstriction recurs after $3-4 \mathrm{~h}$ and reaches a maximum over 6-12 h. Late responses are followed by an increase in airway hyperresponsiveness. These responses occur when IgE on mast cells is cross-linked by an allergen, causing degranulation and the release of histamine, neutral proteases and chemotactic factors, and the production of newly formed mediators, such as cysteinyl leukotrienes and prostaglandin $\mathrm{D}_{2}$. Allergen-induced airway inflammation consists of an increase in airway eosinophils, basophils and, less consistently, neutrophils. These responses are mediated by the trafficking and activation of myeloid dendritic cells into the airways, probably as a result of the release of epithelial cell-derived thymic stromal lymphopoietin, and the release of pro-inflammatory cytokines from type 2 helper T-cells. Allergen inhalation challenge has also been a widely used model to study potential new therapies for asthma and has an excellent negative predictive value for this purpose.

@ERSpublications

Environmental allergens are an important cause of asthma http://ow.ly/NxkGi 


\section{Introduction}

In his publication A Treatise of the Asthma, published in 1698, Floyer identified the periodicity of "asthma fits" and recognised, from his own experience as an asthmatic, that there was a seasonal variation to his asthma symptoms [1]. In 1819, Bозтоск [2] provided the first clinical description of what is now recognised as seasonal allergic rhinitis and asthma. About 10 years later, the terminology of hay fever and hay asthma appeared in the English language [3] because of the relationship of these allergic symptoms to the haying season. In 1873, BLACKLEY [4] published his classic monograph documenting that pollen, grass pollen in particular, was the cause of these seasonal symptoms. Subsequently, many other allergens have been identified and allergic diseases, particularly asthma and allergic rhinitis, have become strikingly more prevalent worldwide [5].

Asthma has been defined by the most recent iteration of the Global Initiative for Asthma (GINA) strategy as "a heterogeneous disease, usually characterized by chronic airway inflammation. It is defined by the history of respiratory symptoms, such as wheeze, shortness of breath, chest tightness and cough that vary over time and intensity, together with variable expiratory airflow limitation" [6]. The physiological hallmarks of asthma are variable airflow limitation and the presence of airway hyperresponsiveness (AHR) to a wide variety of bronchoconstrictor stimuli [7], which is most often documented by measuring the airway responses to inhaled methacholine or histamine [8]. Airway inflammatory responses in asthmatics vary in patients and from time to time. The most characteristic inflammatory response is manifested by the presence of airway eosinophils [9], type 2 helper T (Th2)-cells [10], mast cells [11] and basophils [12]. In some patients, however, an airway neutrophilia is prominent [13], while in a small minority, there is no evidence of an increase in airway inflammatory cells [14]. The relationship of the presence of airway inflammation, the physiological hallmarks of asthma and the development of symptoms remains an area of intense research.

\section{Environmental allergens as a cause of asthma}

There are a number of lines of evidence that environmental allergens are an important cause of persistent asthma and asthma exacerbations. First, the majority of asthmatics (particularly those with childhood-onset asthma) are atopic [15], and studies of birth cohorts have demonstrated a greatly increased risk of diagnosed asthma and AHR in atopic children [16], particularly those sensitised to house dust mite (HDM), cats and dogs [17]. Second, the presence of airway allergic inflammation predisposes children to rhinovirus-induced recurrent wheezing and asthma exacerbations [18], and this interaction between allergic sensitisation and virus exposure predisposes to the development of asthma in childhood [19], possibly through an effect of type- 2 cytokines (such as interleukin (IL)-4 and IL-13) on the innate immune responses to airway viral infection [20]. Third, seasonal asthma, associated with specific environmental allergen exposure, is a well-described clinical entity [21]. Fourth, asthma morbidity and mortality have been associated with inhalation of allergens in soybean in Spain [22], high levels of Alternaria in the USA [23], and thunderstorms and the deposition of rye grass pollen [24]. Fifth, some (but not all) studies have shown that avoidance of allergens results in improvements in AHR, overall asthma control and reduced treatment requirements $[25,26]$. Finally, and perhaps most convincingly, occupational asthma can be caused by inhalation of allergens in the workplace and removal of the patient from this environment can cure asthma [27]. Thus, the weight of evidence strongly supports that the inhalation of environmental allergens plays an important role in the initiation and persistence of asthma in some patients.

\section{Allergen-induced airway responses}

Allergen inhalation by atopic asthmatics in the laboratory results in many of the physiological and inflammatory manifestations of asthma, including reversible airflow obstruction, AHR, and eosinophilic and basophilic airway inflammation. The first description of allergen-induced bronchoconstrictor responses was made by HeRXHeIMER [28] in the early 1950s, who identified two distinct constrictor components, which he called the early (EAR) and late asthmatic responses (LAR). The EAR develops within 10-15 min after inhalation, reaches a maximum within $30 \mathrm{~min}$ and generally resolves by $1-3 \mathrm{~h}$. In approximately $60 \%$ of adults and $80 \%$ of children, bronchoconstriction recurs after 3-4 h and reaches a maximum over $6-12 \mathrm{~h}$ [29]. The prevalence of the LAR appears to be allergen specific, being $>75 \%$ for some allergens, such as HDM or cat allergen, and much less frequent for others, such as grass pollen. Subsequently, СосксROFT et al. [30] demonstrated that allergen-induced airway responses were followed by an increase in AHR to inhaled histamine or methacholine, which could last several days to weeks, and which was greater in patients who develop allergen-induced LAR [31]. These airway responses, although fairly prolonged, do not mimic the chronic, low-dose exposure to environmental allergens. This fact resulted in the development of low-dose inhaled allergen challenge, where doses causing minimal bronchoconstriction are administered daily over 5-7 days. These challenges do not cause late responses, but do cause airway eosinophilia and AHR [32]. Another method used to study the mechanisms of allergen-induced airway responses has been to instil allergen into the airway segment via a bronchoscope and then return to this segment to perform 
bronchial washes at a predetermined time (e.g. at $18 \mathrm{~h}$ ) [33]. This method does not allow for the measurements of the physiological responses to the allergen. Allergen inhalation challenge has become the mainstay for models of asthma developed in many species, including mice [34], rats [35], guinea pigs [36], dogs [37], rabbits [38] and primates [39].

\section{Mechanisms of allergen-induced bronchoconstriction}

The development of airway responses to a specific allergen begins when an inhaled allergen is presented by the professional antigen-presenting cells in the airways, dendritic cells (DCs), to naïve T-cells, which stimulates the development of Th2 cells (figure 1). The Th2 cells produce a variety of cytokines, which promote the production of IgE (IL-4), eosinophilopoiesis (IL-5), mast cell development (IL-9), and goblet cell hyperplasia and AHR (IL-13); these pro-inflammatory cytokines can also be produced by other cells, most notable type 2 innate lymphoid cells. These cytokines are currently best referred to as type- 2 cytokines.

The allergen-induced responses are initiated when IgE binds to high-affinity receptors (FceRI) located on the surface of mast cells and basophils. The IgE is subsequently cross-linked by allergen, causing mast cell degranulation and the release of preformed mediators such as histamine, neutral proteases and chemotactic factors, and the activation of eicosanoid pathways to produce newly formed mediators such as cysteinyl leukotriene $(\mathrm{CysLT}) \mathrm{C}_{4}$ and $\mathrm{CysLTD}_{4}$, and their metabolite cysLTE 4 , as well as prostaglandins $(\mathrm{PG})$, especially $\mathrm{PGD}_{2}$. CysLTs are the most potent bronchoconstrictor mediators yet described [40] and are an important cause of allergen-induced bronchoconstriction. This was initially suggested by the demonstration of increased levels of $\mathrm{LTE}_{4}$ measured in bronchoalveolar lavage (BAL) fluid [41] and in urine after allergen challenge [42]. More convincing evidence was obtained by studies using leukotriene receptor antagonists (LTRAs), which demonstrated that CysLTs account for approximately 50\% of the decrease in the forced expiratory volume in $1 \mathrm{~s}(\mathrm{FEV} 1)$ that occurs during the EAR [43, 44]. CysLTs also increase microvascular permeability [45] and stimulate secretion of mucus [46]. Histamine also contributes to bronchoconstriction during the EAR. Increases in urinary histamine metabolites have been measured during the EAR [47], and combined treatment with antihistamines and LTRAs abolish the EAR [48, 49].

The bronchoconstriction that occurs during the LAR is also caused by cysLTs and histamine release. Once again, the most convincing evidence is that the LAR is partially attenuated by specific LTRAs $[43,50]$ as well as a 5-lipoxygenase activating protein antagonist [51]. Further attenuation is achieved with the combination of an LTRA and an antihistamine [52]. This effect of LTRAs and antihistamine on the LAR is probably mediated through the prevention of airway smooth muscle constriction, airway oedema and mucus production. LTRAs also cause a reduction of allergen-induced airway eosinophilia [44]. In addition, allergen-induced AHR, which is associated with the LAR [31], is also partly mediated by CysLTs. Several studies have demonstrated that treatment with LTRAs also attenuates allergen-induced increases in AHR [53, 54].

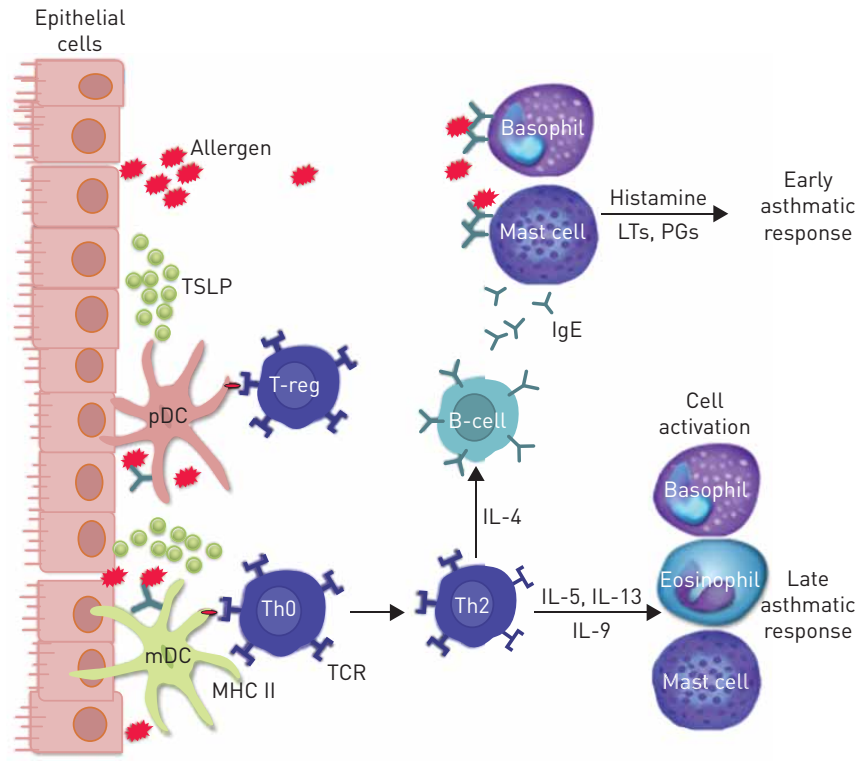

FIGURE 1 The role of airway epithelium, dendritic cells and IgE in the initiation of allergic airway inflammation. TSLP: thymic stromal lymphopoietin; pDC: plasmacytoid dendritic cell; mDC: myeloid dendritic cell; MHC: major histocompatibility complex; Treg: regulatory T-cell; Th: helper T-cell; TCR: T-cell receptor; IL: interleukin; LT: leukotriene; PG: prostaglandin. 
Mast cells have been implicated as the effector cells for the release of the bronchoconstrictor mediators causing the EAR. There is less certainty about the cells of origin of these mediators during the LAR. Both airway basophils and eosinophils are increased during the LAR, and both of these cell types have the ability to synthesise CysLTs $[55,56]$; however, only basophils can produce histamine, which suggests that basophils are, at least in part, involved in causing the LAR. The importance of eosinophils in causing the LAR is less certain, as the one study that examined the effects of an anti-IL-5 human monoclonal antibody (hMAb) on allergen-induced airway responses successfully attenuated the influx of airway eosinophils, but had no effect on the LAR [57].

\section{Mechanisms of allergen-induced airway inflammation}

Allergen-induced late responses are associated with an increase in airway inflammatory cells, which have been measured in airway biopsies [58], BAL $[59,60]$ and induced sputum [61]. The most prominent increase is in airway eosinophils [58,61] but also airway basophils [12] and, less consistently, neutrophils [62].

The allergen-induced airway inflammatory response could be initiated by a number of mechanisms. The cross-linking of IgE on mast cells causes the release of pro-inflammatory cytokines from mast cells, which include IL-3, IL-4, IL-5 and IL-6 [63]. In addition, CysLTs that are also released from mast cells, particularly $\mathrm{LTE}_{4}$, can cause eosinophil chemotaxis in allergic asthmatics [64] and allergen-induced airway eosinophilia is partially attenuated by LTRAs [44, 54]. However, allergic asthmatics who develop an isolated EAR have a smaller increase in airway inflammatory cells when compared to those who develop LARs [65], even though the magnitude of the bronchoconstriction was similar, which implies that mechanisms other than mast cell degranulation and activation are involved. In addition, exercise, which is a stimulus that also causes mast cell degranulation and bronchoconstriction in asthmatics and which is independent of IgE, does not cause eosinophilic airway inflammation [66].

Another important mechanism for allergen-induced airway inflammation involves DCs, which are the most potent lung antigen-presenting cells, and play a central role in initiating primary and secondary immune responses [67]. In humans, two different DC types are distinguished by their dissimilar cell surface antigens and function [68]. Myeloid dendritic cells (mDCs), derived from myeloid precursors, and plasmacytoid dendritic cells ( $\mathrm{pDCs}$ ), derived from lymphoid precursors. In studies in mice, mDCs induce Th2-dominated sensitisation to inhaled allergen, leading to eosinophilic airway inflammation and goblet cell hyperplasia [69], and $\mathrm{mDCs}$ are essential in the presentation of antigen to previously primed Th2-cells, leading to eosinophilic airway inflammation [70]. By contrast, pDCs in mice have been shown to suppress the generation of effecter T-cells, which are induced by mDCs [71], and that the absence of pDCs led to Th2-cell sensitisation and features of asthma [72].

There is a rapid reduction in the numbers of circulating mDCs within $3 \mathrm{~h}$ after inhaled allergen in asthmatic subjects [73] with trafficking of immature mDCs from blood into the airway [74], while trafficking of mDCs from the airways into the regional lymph nodes probably occurs through the lymphatic system [75]. Allergen inhalation also causes an increase in airway DCs in airway biopsy samples [76], and the number of both sputum mDCs and pDCs are higher $24 \mathrm{~h}$ after challenge [77] in asthmatic subjects.

mDCs in peripheral blood do not represent a homogenous population but rather consist of two subsets, $\mathrm{mDC} 1 \mathrm{~s}$ and $\mathrm{mDC} 2 \mathrm{~s}$ [78]. The mDC2s express a high level of thrombomodulin. The morphology, endocytic capacity and maturation are quite similar; however, mDC2s do not express the Fc receptors CD32, CD64 and FcERI [79]. There is a possible role of mDC2s in allergic asthma. Studies have demonstrated that, while all three DC subpopulations are present in asthmatic lungs [80], BAL fluid [81] and in induced sputum [82], $\mathrm{mDC} 2 \mathrm{~s}$ are more frequent than $\mathrm{mDC} 1 \mathrm{~s}$ and $\mathrm{pDCs}$ [80]. Allergen exposure upregulates thrombomodulin in $\mathrm{mDCs}$ and $\mathrm{mDC} 2 \mathrm{~s}$ induce a greater type- 2 cytokine response by allergen-specific T-cells [78]. mDC2s increase in the sputum of subjects with asthma after allergen challenge, suggesting this subtype is involved in the regulation of allergen responses in the lung [83].

The immune and inflammatory processes of the LAR are complex and involve the increase in type-2 airway inflammation, predominantly with eosinophils, but also includes an increase in airway neutrophils [84] and basophils [12]. These increases in airway eosinophils are associated with increases in circulating eosinophil progenitors measured as colony-forming units $24 \mathrm{~h}$ after inhaled allergen, suggesting that inhaled allergen stimulates bone marrow production of these progenitors $[85,86]$. Furthermore, allergen inhalation causes the upregulation of the IL-5 receptor on bone marrow eosinophil progenitors following allergen inhalation [86].

Patients who develop allergen-induced LAR show evidence of impaired regulation by regulatory T (Treg)-cells and an imbalance in the ratio of inhibitory to effector T-cells. It was observed that the ratio of Treg-cells to $\mathrm{CD}^{+}$cells in induced sputum after inhaled allergen is lower in patients with LAR when compared with patients with EAR [87]. 
Finally, epithelial cell-derived mediators have emerged as key players in cellular inflammation in asthmatic airways. In particular, the epithelium-derived cytokine thymic stromal lymphopoietin (TSLP) has been suggested as a master switch for allergic inflammation. GAUvreau et al. [88] have demonstrated that an anti-TSLP hMAb attenuated both allergen-induced EAR and LAR, and reduced the number of eosinophils in induced sputum and the exhaled nitric oxide fraction ( $F$ eNO). Treatment with the hMAb also significantly reduced the numbers of blood and sputum eosinophils and FeNO in these allergic asthmatic subjects prior to allergen challenge. This suggests that there is constitutive epithelial production of TSLP that drives the persisting airway inflammatory response in allergic asthma.

\section{Allergen inhalation challenge to study new drugs for asthma}

The allergen inhalation challenge model is commonly used as an experimental tool to better understand the pathophysiology of allergic asthma and the blocking effects of investigational therapies [29]. The ability of pharmaceutical agents to inhibit allergen-induced outcomes provides reasonable support for clinical efficacy and helps to identify critical pathways involved in allergic airway responses. Each of the currently approved asthma therapies, including inhaled corticosteroids (ICS) [89-91], ICS and long-acting inhaled $\beta_{2}$-agonists [92, 93], LTRAs [50, 94], and anti-IgE [95], show inhibition of late-phase asthmatic responses to inhaled allergen.

Inhibition of the allergen-induced late response is typically selected as the primary outcome in clinical trials assessing efficacy of anti-inflammatory therapies for the treatment of asthma. The late response is most closely associated with airway inflammation. The reproducibility of the late responses has been examined and sample sizes of less than 10 subjects are estimated to provide sufficient power to detect $50 \%$ inhibition with a crossover study design $[61,96]$. Furthermore, parallel-group studies designed with as few as 15 subjects per treatment arm can also detect 50\% inhibition of LAR [97]. As such, clinical trials employing allergen inhalation challenge are generally quite small. Other outcomes could be used to power these studies. These include allergen-induced AHR or airway eosinophilia. These outcomes may be more appropriate for some studies. Allergen-induced AHR is more variable than the LAR and so larger studies would be required. Allergen-induced airway eosinophilia is as reproducible as the LAR and may be an appropriate outcome variable, particularly in studies that are evaluating specific therapies that target eosinophil [98]; however, not all laboratories can measure induced sputum eosinophils and it is often not reported in clinical trials of allergen-induced airway responses.

The selection of the correct subjects to include in trials evaluating new therapies using allergen-induced airway responses is of paramount importance. These need to be mild, stable allergic asthmatic subjects, not on regular anti-inflammatory treatment. Baseline lung function is usually close to normal but such subjects usually have evidence of low-grade persisting baseline airway inflammation, with increased blood and sputum eosinophils and increased FeNO [88]. This careful selection is necessary because of the safety issues of delivering inhaled allergens into the airways of patients with poor asthma control and the fact that regular therapy (with, for example, ICS or LTRA) will markedly influence the allergen-induced airway responses.

The choice of a crossover versus a parallel-group design is usually based on knowledge of the pharmacokinetics of the drug being tested. While crossover studies are smaller in size and can often be completed more quickly, almost all biologics have a long half-life, making a parallel-group design the only practical option.

Historically, the allergen-inhalation challenge model has demonstrated an excellent negative predictive value for the development of new drugs for asthma [99]. There are several examples of potential therapies found to be ineffective in both the allergen challenge model as well as in clinical applications, and these include platelet-activating factor antagonists [100], inhaled formulations of antileukotrienes or anti-IgE [101] and esterase-sensitive steroids [91]. The allergen challenge model has a moderate positive predictive value for identification of efficacious therapies. The number of false positive therapies, to-date, are limited and include inhaled $\mathrm{PGE}_{2}$ [102], furosemide [103] and antihistamines [104]. There have also been potential therapies that have demonstrated inhibition of the LAR but failed to be further developed for treatment of asthma for reasons including unsuitability (adverse events) [105] or lack of business opportunity. To date, there are no cases of therapies giving false-negative results in the allergen challenge model and this statistic is of value to pharmaceutical companies when debating the prospect for further clinical development of a compound.

To test the inhibitory effects of an asthma medication on the magnitude of allergen-induced early and late responses, subjects are challenged with the same dose of allergen after receiving treatment with test therapy and again after receiving treatment with placebo in a randomised crossover study design. When the half-life of the investigational therapy is long (monoclonal antibodies) or unknown, a parallel-group design is utilised with administration of the same dose of allergen determined to induce early and late responses during a screening period. If the onset/offset of activity of the investigational therapy is 
unknown, multiple allergen challenges can be conducted post-dosing to cover a larger timespan. With repeated allergen challenges in either crossover or parallel-group designs, it is critical that sufficient time is allowed between challenges for FEV1 and AHR to return to baseline.

ICS are regarded as the gold standard for comparison of investigational anti-inflammatory therapies, owing to their nearly complete attenuation of the allergen-induced LAR in addition to their suppressive effects on allergen-induced AHR and airway inflammation [90]. Recently, a nonsteroidal glucocorticoid receptor agonist was reported to share these inhibitory properties in the allergen challenge model [106] but the carryover effects observed following treatment with the nonsteroidal glucocorticoid receptor agonist could indicate a longer duration of action than other ICS; however, this needs to be confirmed in a future study. In contrast, regular treatment with salbutamol has been shown to increase the allergen-induced LAR and airway eosinophils (figure 1) [107, 108]. Clearly, the most effective controllers of allergic inflammation in the airways are medications with anti-inflammatory properties, while bronchodilators may mask underlying inflammation and thereby worsen responses to allergen [108, 109].

Many other compounds have been evaluated for their ability to inhibit LAR through targeting of specific inflammatory cells, receptors, enzymes or mediators thought to play central roles in the allergic inflammatory cascade (table 1). Eosinophils have been a key therapeutic target, leading to the development of antibodies against IL-5 (mepolizumab and reslizumab) and its specific receptor subunit IL-5R $\alpha$ (benralizumab). Although anti-IL-5 antibodies have been reported to effectively reduce eosinophil levels in the circulation and airways, one study of treatment with anti-IL-5 did not show any inhibition of the LAR but did markedly attenuate allergen-induced airway eosinophilia (table 2) [57]. However, blocking receptors

TABLE 1 Asthma treatments and new molecular entities studies using inhaled allergen

\begin{tabular}{|c|c|}
\hline Inhaled glucocorticosteroids & Antihistamines \\
\hline Budesonide $[44,90,92,110]$ & Desloratadine [52] \\
\hline Fluticasone furoate $[111,112]$ & Cetirizine [114] \\
\hline Mometasone furoate [113] & Terfenadine [129] \\
\hline Ciclesonide [89] & Protein inhibitors/antagonists \\
\hline Beclomethasone [114] & PDE4 inhibitors $[84,130,131]$ \\
\hline CS receptor agonist [106] & Pan-selectin antagonist $[132,133]$ \\
\hline Long-acting $\beta_{2}$-agonists & Mast cell tryptase inhibitor [134] \\
\hline Vilanterol [111] & CRTH2 antagonist [135] \\
\hline Salmeterol [112] & IL-4R mutant $[136]$ \\
\hline Formoterol [92] & VLA-4 antagonist $[137,138]$ \\
\hline Short-acting $\boldsymbol{\beta}_{2}$-agonist & TNF receptor antagonist [139] \\
\hline Salbutamol $[108,115]$ & Antisense to CCR3 and Bc $[140,141]$ \\
\hline Lipid mediators & CpG immunostimulatory oligonucleotide [142] \\
\hline Leukotriene $A_{4}$ hydrolase inhibitor [116] & PPAR- $\gamma$ agonist [143] \\
\hline 5 -lipoxygenase-activating protein inhibitor $[51,117]$ & Inhaled $A_{2 A}$-receptor agonist [144] \\
\hline CysLT receptor-1 antagonist $[43,44,52,118]$ & Others \\
\hline CysLT1/2 antagonist [119] & Calcium channel blocker [145] \\
\hline Leukotriene $\mathrm{B}_{4}$ receptor antagonist [120] & Cationic airway lining modulator [146] \\
\hline Tachykinin $\mathrm{NK}_{1} / \mathrm{NK}_{2}$ receptor antagonist [121] & Heparin disaccharide [147] \\
\hline Prostaglandin $\mathrm{E}_{2}$ [102] & Cromones $[148,149]$ \\
\hline COX-2 selective inhibitor [122] & Nonsteroidal anti-inflammatory drug $[129,150]$ \\
\hline Platelet-activating factor [100] & Lysine ASA [151] \\
\hline MAbs & Synbiotics [152] \\
\hline IL-13 MAb [97, 123] & $\omega-3$ polyunsaturated fatty acids [153] \\
\hline OX40L MAb [124] & Furosemide [103] \\
\hline IL-5 MAb [57] & \\
\hline $\lg E \operatorname{MAb}[95,125]$ & \\
\hline CD11a MAb [105] & \\
\hline TSLP MAb [88] & \\
\hline M1-prime MAb [126] & \\
\hline IL-9 MAb [127] & \\
\hline C5a MAb [128] & \\
\hline
\end{tabular}

CS: corticosteroid; CytLT: cysteinyl leukotriene; NK: neurokinin; COX: cyclo-oxygenase; MAb: monoclonal antibody; IL: interleukin; TSLP: thymic stromal lymphopoietin; PDE: phosphodiesterase; CRTH2: chemoattractant receptor-homologous molecule expressed on type 2 helper T-cells; IL-4R: IL-4 receptor; VLA: very late antigen; TNF: tumour necrosis factor; Bc: common $\beta$-chain; PPAR: peroxisome proliferator-activated receptor; ASA: acetylsalicylate. 
TABLE 2 Effects of available and experimental asthma treatments on allergen-induced airway responses

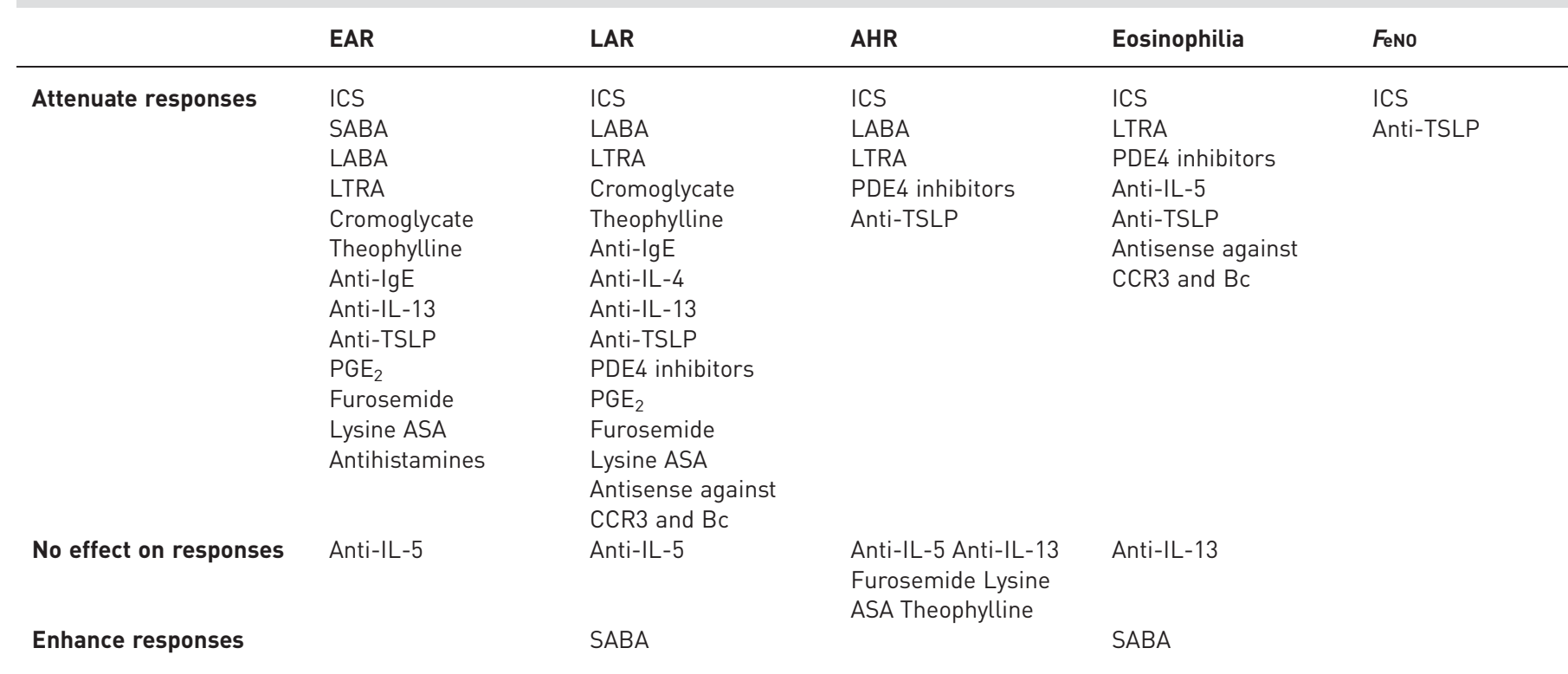

EAR: early asthmatic response; LAR: late asthmatic response; AHR: airway hyperresponsiveness; Feno: fraction of exhaled nitric oxide; ICS: inhaled corticosteroid; SABA: short-acting inhaled $\beta_{2}$-agonist; LABA: long-acting inhaled $\beta_{2}$-agonist; LTRA: leukotriene receptor antagonist; IL: interleukin; TSLP: thymic stromal lymphopoietin; PG: prostaglandin; ASA: acetylsalicylate; PDE: phosphodiesterase; Bc: common $\beta$-chain.

of the eosinophil growth factors IL-3, IL-5 and granulocyte-macrophage colony-stimulating factor in combination with the chemokine receptor CCR3 has been shown to inhibit airway eosinophils and the LAR [140]. This suggests that either antieosinophil therapy needs to effectively block eosinophilopoiesis or that other proallergy cells sharing this repertoire of receptors, such as mast cells and basophils, need to be targeted in combination with the eosinophil for effective control of allergic inflammation.

Therapies directed at other cytokines central to the pathogenesis of allergic asthma have been generated and tested in the allergen challenge model. Due to its pleiotropic role in asthma, IL-13 has been the focus of considerable attention. Several therapeutic approaches have been utilised to impede the actions of IL-13, including monoclonal antibodies blocking binding to IL-13R $\alpha 1$ (IMA-026) or IL-4R $\alpha$ (IMA-638 and lebrikizumab) and therapies blocking both receptors, such as an IL-4 variant (pitrakinra). Studies conducted using the allergen challenge model consistently demonstrated that blockade of the IL-4R $\alpha$-binding domain of IL-13 attenuates the LAR [97, 123, 154], while blockade of the IL-13R $\alpha 1$-binding domain of IL-13 binding to has no significant effect [97]. Furthermore, blockade of IL-13/IL-4R $\alpha$ binding (dupilumab) was

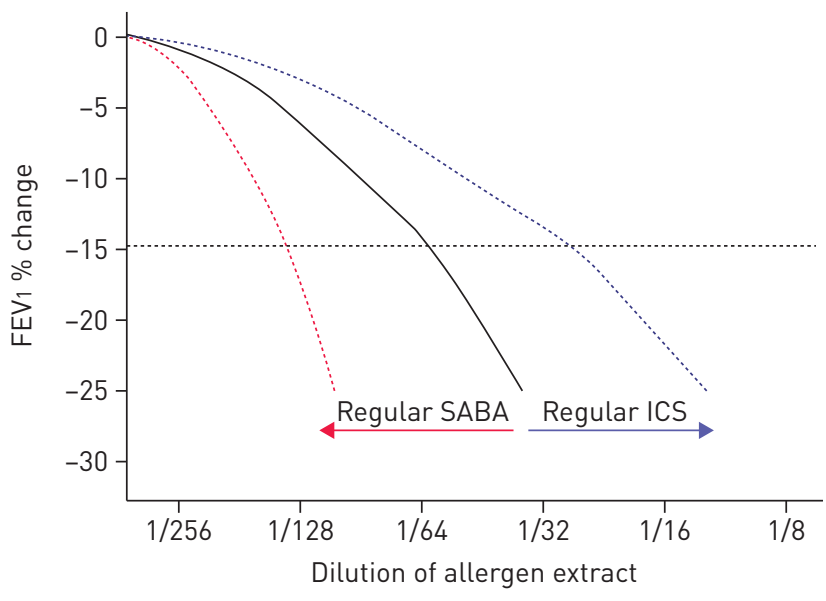

FIGURE 2 The provocative concentration of allergen causing a $15 \%$ fall in forced expiratory volume in $1 \mathrm{~s}$ (FEV 1 ) is inhibited by anti-inflammatory drugs (inhaled corticosteroids) and can be exaggerated, as observed following regular use of salbutamol. SABA: short acting $\beta_{2}$-agonist; ICS: inhaled corticosteroid. 


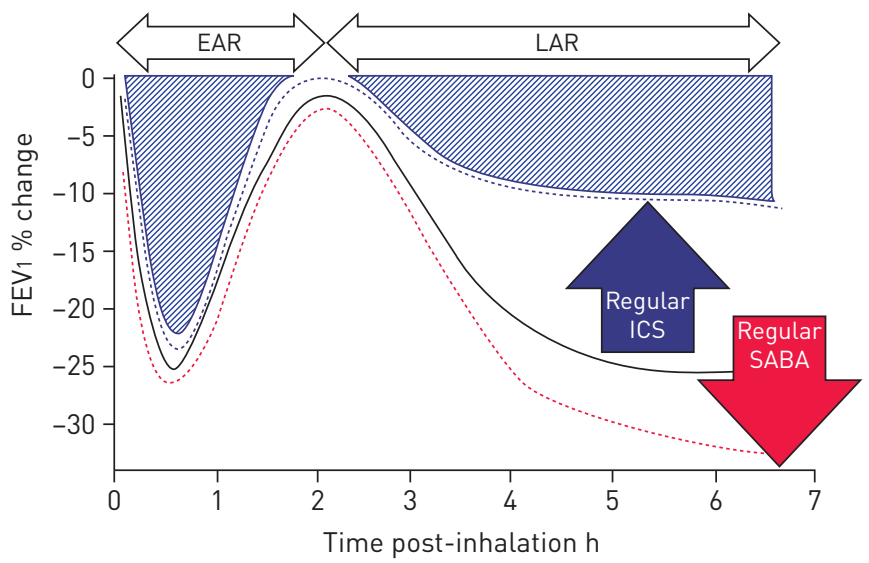

FIGURE 3 Allergen-induced early (0-2 h) (EAR) and late (3-7 h) airway responses (LAR). The LAR is inhibited by anti-inflammatory drugs (inhaled corticosteroids (ICS)). The LAR can be exaggerated, as observed following regular use of salbutamol. SABA: short acting $\beta_{2}$-agonist.

associated with improved lung function when studied in patients with uncontrolled asthma [155], demonstrating consistency of efficacy between the allergen challenge model and larger asthma clinical trials. More recently, an antibody to TSLP (AMG 157) has been reported to attenuate the LAR and many other allergen responses measured; anti-TSLP antibody inhibited the allergen-induced EAR, the shift to AHR, the increase in circulating and airway eosinophils, and the elevated levels of exhaled nitric oxide [88]. Unexpectedly, the anti-TSLP antibody also reduced the low-grade inflammation (circulating and blood eosinophils, and $\mathrm{FeNO}$ ) in the mild asthmatic subjects measured at baseline before allergen challenge. This comprehensive reduction in inflammation has not been observed before, not even following treatment with inhaled steroids [89]. It is believed that the upstream position of TSLP in the allergic cascade is critical for the success of the anti-TSLP approach in this model.

In another model of allergen challenge, inhibition of the early-phase response can be more carefully examined using an approach whereby increasing concentrations of allergen are administered until a $20 \%$ or $15 \%$ fall in FEV1 is reached and the provocative concentration of the allergen causing that fall (PC20 or $\mathrm{PC} 15$, respectively) is calculated. An elevation in the $\mathrm{PC}_{20}$ following drug treatment versus placebo treatment demonstrates a protective effect on allergen-induced bronchoconstriction. Drugs that block components of the allergic cascade, for example, by preventing crosslinking of IgE receptors by allergen (anti-IgE) $[125,156]$ or by interfering with mediators of bronchoconstriction (CysLTs and histamine), have been shown to increase the allergen PC20 [49]. Treatment with antihistamines [52], antileukotrienes [44] or anti-IgE [95] also attenuate the fall in FEV1 during the early and late responses after allergen challenge, which suggests that events occurring during the early response are linked to the development of the late response. Pre-treatment with $\beta$-adrenergic receptor agonists also increases the allergen PC20 [157] but the mechanism is by functional antagonism rather than by blocking inflammatory pathways. Surprisingly, regular use of salbutamol has been reported to increase the responsiveness to allergen, as shown by a decrease in the allergen PC20 [109] (figure 2). Consistent with this finding, when allergen is inhaled after regular use of salbutamol, there is enhancement of the EAR and LAR when compared to the response after placebo [107] (figure 3). The mechanism for the increase in LAR may involve increased airway inflammation [108]. While the allergen challenge model has been used for proof of concept in drug development to identify key therapies that reduce responses to inhaled allergen, the model can also identify therapies that increase responses to inhaled allergen.

\section{Conclusions}

Environmental allergens are an important cause of asthma, and their inhalation can contribute to loss of asthma control and exacerbations. Allergen inhalation challenge has been a useful clinical model to examine the mechanisms of allergen-induced airway responses and inflammation. It has also been a widely used model to study potential new therapies for asthma and has an excellent negative predictive value for this purpose. The predictive value of this clinical model for new drug development is likely because allergen-induced airway responses include physiological and inflammatory responses, which are central to asthma symptoms and exacerbations, such as bronchoconstriction, airway oedema, mucus production, and eosinophilic and basophilic airway inflammation. The inhaled allergen challenge model will probably continue to be extensively employed for studying the pathogenesis of airways inflammation and for assessment of new therapeutics in clinical proof-of-concept studies. 


\section{References}

Sakula A. Sir John Floyer's A Treatise of the Asthma (1698). Thorax 1984; 39: 248-254.

Bostock J. Case of a periodical affection of the eyes and chest. Med Chir Trans 1819; 10: 161-164.

Bostock J. Of the Catarrus Aestivas or summer catarrh. Med Chir Tran 1828; 14: 437-446.

Blackley CH. Experimental Researches on the Cause and Nature of Catarrhus Aestivus (Hay-Fever or Hay-Asthma). London, Balliere Tindall \& Cox, 1873.

5 Asher MI, Montefort S, Bjorksten B, et al. Worldwide time trends in the prevalence of symptoms of asthma allergic rhinoconjunctivitis, and eczema in childhood: ISAAC Phases One and Three repeat multicountry cross-sectional surveys. Lancet 2006; 368: 733-743.

6 Global Initiative for Asthma. Global Strategy for Asthma Management and Prevention. Revised 2014. http://www. ginasthma.org/local/uploads/files/GINA_Report_2014_Aug12_1.pdf Date last updated: August 12, 2014.

7 Hargreave FE, Ryan G, Thomson NC, et al. Bronchial responsiveness to histamine or methacholine in asthma: measurement and clinical significance. Eur J Respir Dis 1982; 121: Suppl., 79-88.

8 O’Byrne PM, Inman MD. Airway hyperresponsiveness. Chest 2003; 123: 411S-416S.

9 Kirby JG, Hargreave FE, Gleich GJ, et al. Bronchoalveolar cell profiles of asthmatic and nonasthmatic subjects. Am Rev Respir Dis 1987; 136: 379-383.

10 Robinson DS, Hamid Q, Ying S, et al. Predominant $\mathrm{T}_{\mathrm{H} 2}$-like bronchoalveolar T-lymphocyte population in atopic asthma. N Engl J Med 1992; 326: 298-304.

11 Sont JK, Han J, van Krieken JM, et al. Relationship between the inflammatory infiltrate in bronchial biopsy specimens and clinical severity of asthma in patients treated with inhaled steroids. Thorax 1996; 51: 496-502.

12 Gauvreau GM, Lee JM, Watson RM, et al. Increased numbers of both airway basophils and mast cells in sputum after allergen inhalation challenge of atopic asthmatics. Am J Respir Crit Care Med 2000; 161: 1473-1478.

13 Gibson PG, Simpson JL, Saltos N. Heterogeneity of airway inflammation in persistent asthma: evidence of neutrophilic inflammation and increased sputum interleukin-8. Chest 2001; 119: 1329-1336.

14 Simpson JL, Scott R, Boyle MJ, et al. Inflammatory subtypes in asthma: assessment and identification using induced sputum. Respirology 2006; 11: 54-61.

15 Sears MR, Burrows B, Flannery EM, et al. Atopy in childhood. I. Gender and allergen related risks for development of hay fever and asthma. Clin Exp Allergy 1993; 23: 941-948.

16 Simpson A, Tan VY, Winn J, et al. Beyond atopy: multiple patterns of sensitization in relation to asthma in a birth cohort study. Am J Respir Crit Care Med 2010; 181: 1200-1206.

17 Sears MR, Herbison GP, Holdaway MD, et al. The relative risks of sensitivity to grass pollen, house dust mite and cat dander in the development of childhood asthma. Clin Exp Allergy 1989; 19: 419-424.

18 Green RM, Custovic A, Sanderson G, et al. Synergism between allergens and viruses and risk of hospital admission with asthma: case-control study. BMJ 2002; 324: 763

19 Busse WW, Gern JE. Asthma and infections: is the risk more profound than previously thought? J Allergy Clin Immunol 2014; 134: 260-261.

20 Contoli M, Ito K, Padovani A, et al. Th2 cytokines impair innate immune responses to rhinovirus in respiratory epithelial cells. Allergy 2015 [In press DOI: 10.1111/all.12627].

21 Boulet LP, Cartier A, Thomson NC, et al. Asthma and increases in nonallergic bronchial responsiveness from seasonal pollen exposure. J Allergy Clin Immunol 1983; 71: 399-406.

22 Anto JM, Sunyer J, Rodriguez-Roisin R, et al. Community outbreaks of asthma associated with inhalation of soybean dust. N Engl J Med 1989; 320: 1097-1102.

23 O'Hollaren MT, Yunginger JW, Offord KP, et al. Exposure to an aeroallergen as a possible precipitating factor in respiratory arrest in young patients with asthma. N Engl J Med 1991; 324: 359-363.

24 Bellomo R, Gigliotti P, Treloar A, et al. Two consecutive thunderstorm associated epidemics of asthma in the city of Melbourne. The possible role of rye grass pollen. Med J Aust 1992; 156: 834-837.

25 Platts-Mills TA, Tovey ER, Mitchell EB, et al. Reduction of bronchial hyperreactivity during prolonged allergen avoidance. Lancet 1982; 2: 675-678.

26 van VE, van den Bos JW, Benckhuijsen JA, et al. Effect of allergen avoidance at high altitude on direct and indirect bronchial hyperresponsiveness and markers of inflammation in children with allergic asthma. Thorax 1996; 51: 582-584.

27 Tarlo SM, Lemiere C. Occupational asthma. N Engl J Med 2014; 370: 640-649.

28 Herxheimer H. Bronchial obstruction induced by allergens, histamine and acetyl-beta-methylcholinechloride Int Arch Allergy Appl Immunol 1951; 2: 27-39.

29 Diamant Z, Gauvreau GM, Cockcroft DW, et al. Inhaled allergen bronchoprovocation tests. J Allergy Clin Immunol 2013; 132: 1045-1055.

30 Cockcroft DW, Ruffin RE, Dolovich J, et al. Allergen-induced increase in non-allergic bronchial reactivity. Clin Allergy 1977; 7: 503-513.

31 Cartier A, Thomson NC, Frith PA, et al. Allergen-induced increase in bronchial responsiveness to histamine: relationship to the late asthmatic response and change in airway caliber. J Allergy Clin Immunol 1982; 70: 170-177.

32 Sulakvelidze I, Inman MD, Rerecich $\mathrm{T}$, et al. Increases in airway eosinophils and interleukin-5 with minimal bronchoconstriction during repeated low-dose allergen challenge in atopic asthmatics. Eur Respir J 1998; 11: 821-827.

33 Virchow JCJr, Walker C, Hafner D, et al. T cells and cytokines in bronchoalveolar lavage fluid after segmental allergen provocation in atopic asthma. Am J Respir Crit Care Med 1995; 151: 960-968.

34 Inman MD, Ellis R, Wattie J, et al. Allergen-induced increase in airway responsiveness, airway eosinophilia, and bone-marrow eosinophil progenitors in mice. Am J Respir Cell Mol Biol 1999; 21: 473-479.

35 Labonte I, Hassan M, Risse PA, et al. The effects of repeated allergen challenge on airway smooth muscle structural and molecular remodeling in a rat model of allergic asthma. Am J Physiol Lung Cell Mol Physiol 2009; 297: L698-L705.

36 Bai TR, Wang ZL, Walker B, et al. Chronic allergic inflammation induces replication of airway smooth muscle cells in vivo in guinea pigs. Chest 1995; 107: Suppl., 93S.

37 Woolley MJ, Denburg JA, Ellis R, et al. Allergen-induced changes in bone marrow progenitors and airway responsiveness in dogs and the effect of inhaled budesonide on these parameters. Am J Respir Cell Mol Biol 1994; 11: 600-606. 

obstruction. Eosinophil infiltration and heightened airway responsiveness in allergic rabbits. Am Rev Respir Dis 1990; 142: 587-593.

39 Hicks A, Goodnow RJr, Cavallo G, et al. Effects of LTB4 receptor antagonism on pulmonary inflammation in rodents and non-human primates. Prostaglandins Other Lipid Mediat 2010; 92: 33-43.

40 Adelroth E, Morris MM, Hargreave FE, et al. Airway responsiveness to leukotrienes C4 and D4 and to methacholine in patients with asthma and normal controls. N Engl J Med 1986; 315: 480-484.

41 Wenzel SE, Larsen GL, Johnston K, et al. Elevated levels of leukotriene C4 in bronchoalveolar lavage fluid from atopic asthmatics after endobronchial allergen challenge. Am Rev Respir Dis 1990; 142: 112-119.

42 Manning PJ, Rokach J, Malo JL, et al. Urinary leukotriene E4 levels during early and late asthmatic responses. J Allergy Clin Immunol 1990; 86: 211-220.

43 Hamilton A, Faiferman I, Stober P, et al. Pranlukast, a cysteinyl leukotriene receptor antagonist, attenuates allergen-induced early- and late-phase bronchoconstriction and airway hyperresponsiveness in asthmatic subjects. J Allergy Clin Immunol 1998; 102: 177-183.

44 Leigh R, Vethanayagam D, Yoshida M, et al. Effects of montelukast and budesonide on airway responses and airway inflammation in asthma. Am J Respir Crit Care Med 2002; 166: 1212-1217.

45 Woodward DF, Weichman BM, Gill CA, et al. The effect of synthetic leukotrienes on tracheal microvascular permeability. Prostaglandins 1983; 25: 131-142.

46 Piper PJ, Conroy DM, Costello JF, et al. Leukotrienes and inflammatory lung disease. Ann NY Acad Sci 1991; 629: 112-119.

47 Oosting E, Keyzer JJ. Measurement of urinary N $\tau$-methylhistamine excretion: correlation of a newly developed radioimmunoassay (RIA) with gas chromatography mass spectrometry (GCMS). Agents Actions 1991; 33: 215-217. Roquet A, Dahlen B, Kumlin M, et al. Combined antagonism of leukotrienes and histamine produces predominant inhibition of allergen-induced early and late phase airway obstruction in asthmatics. Am J Respir Crit Care Med 1997; 155: 1856-1863.

49 Davis BE, Todd DC, Cockcroft DW. Effect of combined montelukast and desloratadine on the early asthmatic response to inhaled allergen. J Allergy Clin Immunol 2005; 116: 768-772.

50 Taylor IK, O'Shaughnessy KM, Fuller RW, et al. Effect of cysteinyl-leukotriene receptor antagonist ICI 204.219 on allergen-induced bronchoconstriction and airway hyperreactivity in atopic subjects. Lancet 1991; 337: 690-694.

51 Hamilton AL, Watson RM, Wyile G, et al. Attenuation of early and late phase allergen-induced bronchoconstriction in asthmatic subjects by a 5-lipoxygenase activating protein antagonist, BAYx 1005. Thorax 1997; 52: 348-354.

52 Davis BE, Illamperuma C, Gauvreau GM, et al. Single-dose desloratadine and montelukast and allergen-induced late airway responses. Eur Respir J 2009; 33: 1302-1308.

53 Hamilton A, Faiferman I, Stober P, et al. Pranlukast, a cysteinyl leukotriene receptor antagonist, attenuates allergen-induced early- and late-phase bronchoconstriction and airway hyperresponsiveness in asthmatic subjects. J Allergy Clin Immunol 1998; 102: 177-183.

54 Parameswaran K, Watson R, Gauvreau GM, et al. The effect of pranlukast on allergen-induced bone marrow eosinophilopoiesis in subjects with asthma. Am J Respir Crit Care Med 2004; 169: 915-920.

55 Holgate ST. The role of mast cells and basophils in inflammation. Clin Exp Allergy 2000; 30: Suppl. 1, $28-32$.

56 Bruynzeel PL, Kok PT, Hamelink ML, et al. Exclusive leukotriene C4 synthesis by purified human eosinophils induced by opsonized zymosan. FEBS Lett 1985; 189: 350-354.

57 Leckie MJ, ten BA, Khan J, et al. Effects of an interleukin-5 blocking monoclonal antibody on eosinophils, airway hyper-responsiveness, and the late asthmatic response. Lancet 2000; 356: 2144-2148.

58 Beasley R, Roche WR, Roberts JA, et al. Cellular events in the bronchi in mild asthma and after bronchial provocation. Am Rev Respir Dis 1989; 139: 806-817.

59 Djukanovic R, Feather I, Gratziou C, et al. Effect of natural allergen exposure during the grass pollen season on airways inflammatory cells and asthma symptoms. Thorax 1996; 51: 575-581.

60 Jarjour NN, Calhoun WJ, Kelly EA, et al. The immediate and late allergic response to segmental bronchopulmonary provocation in asthma. Am J Respir Crit Care Med 1997; 155: 1515-1521.

61 Gauvreau GM, Watson RM, O’Byrne PM. Kinetics of allergen-induced airway eosinophilic cytokine production and airway inflammation. Am J Respir Crit Care Med 1999; 160: 640-647.

62 Gauvreau GM, Inman MD, Kelly M, et al. Increased levels of airway neutrophils reduce the inhibitory effects of inhaled glucocorticosteroids on allergen-induced airway eosinophils. Can Respir J 2002; 9: 26-32.

63 Plaut M, Pierce JH, Watson CJ, et al. Mast cell lines produce lymphokines in response to cross-linkage of FceRI or to calcium ionophores. Nature 1989; 339: 64-67.

64 Gauvreau GM, Parameswaran KN, Watson RM, et al. Inhaled leukotriene $\mathrm{E}_{4}$, but not leukotriene $\mathrm{D}_{4}$, increased airway inflammatory cells in subjects with atopic asthma. Am J Respir Crit Care Med 2001; 164: 1495-1500.

65 Imaoka H, Gauvreau GM, Watson RM, et al. Sputum inflammatory cells and allergen-induced airway responses in allergic asthmatic subjects. Allergy 2011; 66: 1075-1080.

66 Gauvreau GM, Ronnen GM, Watson RM, et al. Exercise-induced bronchoconstriction does not cause eosinophilic airway inflammation or airway hyperresponsiveness in subjects with asthma. Am J Respir Crit Care Med 2000; 162: 1302-1307.

67 Lambrecht BN. The dendritic cell in allergic airway diseases: a new player to the game. Clin Exp Allergy 2001; 31: $206-218$.

68 Upham JW, Stumbles PA. Why are dendritic cells important in allergic diseases of the respiratory tract? Pharmacol Ther 2003; 100: 75-87.

69 Lambrecht BN, De VM, Coyle AJ, et al. Myeloid dendritic cells induce Th2 responses to inhaled antigen, leading to eosinophilic airway inflammation. J Clin Invest 2000; 106: 551-559.

70 Lambrecht BN, Salomon B, Klatzmann D, et al. Dendritic cells are required for the development of chronic eosinophilic airway inflammation in response to inhaled antigen in sensitized mice. J Immunol 1998; 160: 4090-4097.

71 de Heer HJ, Hammad H, Soullie T, et al. Essential role of lung plasmacytoid dendritic cells in preventing asthmatic reactions to harmless inhaled antigen. J Exp Med 2004; 200: 89-98.

72 Kool M, van Nimwegen M, Willart MA, et al. An anti-inflammatory role for plasmacytoid dendritic cells in allergic airway inflammation. J Immunol 2009; 183: 1074-1082. 
Upham JW, Denburg JA, O’Byrne PM. Rapid response of circulating myeloid dendritic cells to inhaled allergen in asthmatic subjects. Clin Exp Allergy 2002; 32: 818-823.

Parameswaran K, Liang H, Fanat A, et al. Role for cysteinyl leukotrienes in allergen-induced change in circulating dendritic cell number in asthma. J Allergy Clin Immunol 2004; 114: 73-79.

Farrell E, O'Connor TM, Duong M, et al. Circulating myeloid and plasmacytoid dendritic cells after allergen inhalation in asthmatic subjects. Allergy 2007; 62: 1139-1145.

Moller GM, Overbeek SE, Van Helden-Meeuwsen CG, et al. Increased numbers of dendritic cells in the bronchial mucosa of atopic asthmatic patients: downregulation by inhaled corticosteroids. Clin Exp Allergy 1996; 26: 517-524.

Dua B, Watson RM, Gauvreau GM, et al. Myeloid and plasmacytoid dendritic cells in induced sputum after allergen inhalation in subjects with asthma. J Allergy Clin Immunol 2010; 126: 133-139.

Yerkovich ST, Roponen M, Smith ME, et al. Allergen-enhanced thrombomodulin (blood dendritic cell antigen 3, CD141) expression on dendritic cells is associated with a TH2-skewed immune response. J Allergy Clin Immunol 2009; 123: 209-216.

Dzionek A, Fuchs A, Schmidt P, et al. BDCA-2, BDCA-3, and BDCA-4: three markers for distinct subsets of dendritic cells in human peripheral blood. J Immunol 2000; 165: 6037-6046.

Demedts IK, Brusselle GG, Vermaelen KY, et al. Identification and characterization of human pulmonary dendritic cells. Am J Respir Cell Mol Biol 2005; 32: 177-184.

Tsoumakidou M, Tzanakis N, Papadaki HA, et al. Isolation of myeloid and plasmacytoid dendritic cells from human bronchoalveolar lavage fluid. Immunol Cell Biol 2006; 84: 267-273.

McCarthy NE, Jones HA, Marks NA, et al. Inhaled allergen-driven CD1c up-regulation and enhanced antigen uptake by activated human respiratory-tract dendritic cells in atopic asthma. Clin Exp Allergy 2007; 37: 72-82.

Dua B, Tang W, Watson R, et al. Myeloid dendritic cells type 2 after allergen inhalation in asthmatic subjects. Clin Exp Allergy 2014; 44: 921-929.

Gauvreau GM, Boulet LP, Schmid-Wirlitsch C, et al. Roflumilast attenuates allergen-induced inflammation in mild asthmatic subjects. Respir Res 2011; 12: 140.

Wood LJ, Inman MD, Watson RM, et al. Changes in bone marrow inflammatory cell progenitors after inhaled allergen in asthmatic subjects. Am J Respir Crit Care Med 1998; 157: 99-105.

Sehmi R, Wood LJ, Watson R, et al. Allergen-induced increases in IL-5 receptor $\alpha$-subunit expression on bone marrow-derived $\mathrm{CD} 34^{+}$cells from asthmatic subjects. A novel marker of progenitor cell commitment towards eosinophilic differentiation. J Clin Invest 1997; 100: 2466-2475.

Kinoshita T, Baatjes A, Smith SG, et al. Natural regulatory T cells in isolated early responders compared with dual responders with allergic asthma. J Allergy Clin Immunol 2014; 133: 696-703.

Gauvreau GM, O'Byrne PM, Boulet LP, et al. Effects of an anti-TSLP antibody on allergen-induced asthmatic responses. N Engl J Med 2014; 370: 2102-2110.

Gauvreau GM, Boulet LP, Postma DS, et al. Effect of low-dose ciclesonide on allergen-induced responses in subjects with mild allergic asthma. J Allergy Clin Immunol 2005; 116: 285-291.

Gauvreau GM, Doctor J, Watson RM, et al. Effects of inhaled budesonide on allergen-induced airway responses and airway inflammation. Am J Respir Crit Care Med 1996; 154: 1267-1271.

Kidney JC, Boulet LP, Hargreave FE, et al. Evaluation of single-dose inhaled corticosteroid activity with an allergen challenge model. J Allergy Clin Immunol 1997; 100: 65-70.

Kelly MM, O'Connor TM, Leigh R, et al. Effects of budesonide and formoterol on allergen-induced airway responses, inflammation, and airway remodeling in asthma. J Allergy Clin Immunol 2010; 125: 349-356.

Oliver A, Bjermer L, Quinn D, et al. Modulation of allergen-induced bronchoconstriction by fluticasone furoate and vilanterol alone or in combination. Allergy 2013; 68: 1136-1142.

Diamant Z, Grootendorst DC, Veselic-Charvat M, et al. The effect of montelukast (MK-0476), a cysteinyl leukotriene receptor antagonist, on allergen-induced airway responses and sputum cell counts in asthma. Clin Exp Allergy 1999; 29: 42-51.

Fahy JV, Fleming HE, Wong HH et al. The effect of an anti-IgE monoclonal antibody on the early- and late-phase responses to allergen inhalation in asthmatic subjects. Am J Respir Crit Care Med 1997; 155: 1828-1834.

Inman MD, Watson R, Cockcroft DW, et al. Reproducibility of allergen-induced early and late asthmatic responses. J Allergy Clin Immunol 1995; 95: 1191-1195.

Gauvreau GM, Boulet LP, Cockcroft DW, et al. Effects of interleukin-13 blockade on allergen-induced airway responses in mild atopic asthma. Am J Respir Crit Care Med 2011; 183: 1007-1014.

Gauvreau GM, Watson RM, Rerecich TJ, et al. Repeatability of allergen-induced airway inflammation. J Allergy Clin Immunol 1999; 104: 66-71.

Boulet LP, Gauvreau G, Boulay ME, et al. The allergen bronchoprovocation model: an important tool for the investigation of new asthma anti-inflammatory therapies. Allergy 2007; 62: 1101-1110. induced asthmatic responses. Thorax 1993; 48: 594-598.

Fahy JV, Cockcroft DW, Boulet LP, et al. Effect of aerosolized anti-IgE (E25) on airway responses to inhaled allergen in asthmatic subjects. Am J Respir Crit Care Med 1999; 160: 1023-1027.

Gauvreau GM, Watson RM, O’Byrne PM. Protective effects of inhaled PGE2 on allergen-induced airway responses and airway inflammation. Am J Respir Crit Care Med 1999; 159: 31-36.

Bianco S, Pieroni MG, Refini RM, et al. Protective effect of inhaled furosemide on allergen-induced early and late asthmatic reactions. N Engl J Med 1989; 321: 1069-1073.

Watt GD, Bui TC, Bewtra AK, et al. Protective effect of lodoxamide tromethamine on allergen inhalation challenge. J Allergy Clin Immunol 1980; 66: 286-294.

Gauvreau GM, Becker AB, Boulet LP, et al. The effects of an anti-CD11a mAb, efalizumab, on allergen-induced airway responses and airway inflammation in subjects with atopic asthma. J Allergy Clin Immunol 2003; 112: 331-338. Gauvreau GM, Boulet LP, Leigh R, et al. A nonsteroidal glucocorticoid receptor agonist inhibits allergen-induced late asthmatic responses. Am J Respir Crit Care Med 2015; 191: 161-167.

Cockcroft DW, O'Byrne PM, Swystun VA, et al. Regular use of inhaled albuterol and the allergen-induced late asthmatic response. J Allergy Clin Immunol 1995; 96: 44-49. 
Gauvreau GM, Jordana M, Watson RM, et al. Effect of regular inhaled albuterol on allergen-induced late responses and sputum eosinophils in asthmatic subjects. Am J Respir Crit Care Med 1997; 156: $1738-1745$.

Cockcroft DW, McParland CP, Britto SA, et al. Regular inhaled salbutamol and airway responsiveness to allergen. Lancet 1993; 342: 833-837.

Wood LJ, Sehmi R, Gauvreau GM, et al. An inhaled corticosteroid, budesonide, reduces baseline but not allergen-induced increases in bone marrow inflammatory cell progenitors in asthmatic subjects. Am J Respir Crit Care Med 1999; 159: 1457-1463.

Oliver A, Bjermer L, Quinn D, et al. Modulation of allergen-induced bronchoconstriction by fluticasone furoate and vilanterol alone or in combination. Allergy 2013; 68: 1136-1142.

Paggiaro PL, Giannini D, Di FA, et al. Minimal tolerance to the bronchoprotective effect of inhaled salmeterol/ fluticasone combination on allergene challenge. Pulm Pharmacol Ther 2006; 19: 425-429.

Inman MD, Watson RM, Rerecich T, et al. Dose-dependent effects of inhaled mometasone furoate on airway function and inflammation after allergen inhalation challenge. Am J Respir Crit Care Med 2001; 164: 569-574.

Bentley AM, Walker S, Hanotte F, et al. A comparison of the effects of oral cetirizine and inhaled beclomethasone on early and late asthmatic responses to allergen and the associated increase in airways hyperresponsiveness. Clin Exp Allergy 1996; 26: 909-917.

Swystun VA, Gordon JR, Davis EB, et al. Mast cell tryptase release and asthmatic responses to allergen increase with regular use of salbutamol. J Allergy Clin Immunol 2000; 106: 57-64.

Barchuk W, Lambert J, Fuhr R, et al. Effects of JNJ-40929837, a leukotriene A4 hydrolase inhibitor, in a bronchial allergen challenge model of asthma. Pulm Pharmacol Ther 2014; 29: 15-23.

Kent SE, Boyce M, Diamant Z, et al. The 5-lipoxygenase-activating protein inhibitor, GSK2190915, attenuates the early and late responses to inhaled allergen in mild asthma. Clin Exp Allergy 2013; 43: 177-186.

Boulet LP, Turcotte H, Laviolette M, et al. Inhibitory effects of BAY x 7195, a CYS leukotriene 1 receptor antagonist, on allergen-induced asthmatic responses. Ann Allergy Asthma Immunol 1997; 79: 155-161.

Gauvreau GM, Boulet LP, FitzGerald JM, et al. Effects of a dualCysLT1/2 antagonost, ONO-6950, on allergen-indcued airway responses in subkects with mild allergic asthma. Eur Respir J 2014; 44: Suppl. 58, P2813.

Evans DJ, Barnes PJ, Spaethe SM, et al. Effect of a leukotriene B4 receptor antagonist, LY293111, on allergen induced responses in asthma. Thorax 1996; 51: 1178-1184.

Boot JD, de HS, Tarasevych S, et al. Effect of an NK1/NK2 receptor antagonist on airway responses and inflammation to allergen in asthma. Am J Respir Crit Care Med 2007; 175: 450-457.

Daham K, James A, Balgoma D, et al. Effects of selective COX-2 inhibition on allergen-induced bronchoconstriction and airway inflammation in asthma. J Allergy Clin Immunol 2014; 134: 306-313.

Scheerens H, Arron JR, Zheng Y, et al. The effects of lebrikizumab in patients with mild asthma following whole lung allergen challenge. Clin Exp Allergy 2014; 44: 38-46.

Gauvreau GM, Boulet LP, Cockcroft DW, et al. OX40L blockade and allergen-induced airway responses in subjects with mild asthma. Clin Exp Allergy 2014; 44: 29-37.

Gauvreau GM, Boulet LP, Leigh Rj, et al. Efficacy and safety of multiple doses of QGE031 (ligelizumab) versus omalizumab and placebo in inhibiting the allergen-induced early asthmatic response. Eur Respir J 2014: Suppl. 58, 2910.

Gauvreau GM, Harris JM, Boulet LP, et al. Targeting membrane-expressed IgE B cell receptor with an antibody to the M1 prime epitope reduces IgE production. Sci Transl Med 2014; 6: 243ra85.

Gauvreau GM, Boulet LP, Parker JM, et al. A randomized double-blind placebo controlled multicenter study to evaluate the efficacy of a humanized interleukin-9 monoclonal antibody (MEDI-528) on the late asthmatic response in adults with atopic asthma. Am J Respir Crit Care Med 2009; 179: A3639.

Gauvreau GM, Boulet LP, Severino B, et al. The effect of C5 inhibition on allergen-induced asthmatic responses. Allergy 2009; 64: Suppl. 90, 16.

Hamid M, Rafferty P, Holgate ST. The inhibitory effect of terfenadine and flurbiprofen on early and late-phase bronchoconstriction following allergen challenge in atopic asthma. Clin Exp Allergy 1990; 20: 261-267.

Leaker BR, Singh D, Ali FY, et al. The effect of the novel phosphodiesterase-4 inhibitor MEM 1414 on the allergen induced responses in mild asthma. BMC Pulm Med 2014; 14 : 166.

Singh D, Petavy F, Macdonald AJ, et al. The inhaled phosphodiesterase 4 inhibitor GSK256066 reduces allergen challenge responses in asthma. Respir Res 2010; 11: 26.

Avila PC, Boushey HA, Wong H, et al. Effect of a single dose of the selectin inhibitor TBC1269 on early and late asthmatic responses. Clin Exp Allergy 2004; 34: 77-84.

Beeh KM, Beier J, Meyer M, et al. Bimosiamose, an inhaled small-molecule pan-selectin antagonist, attenuates late asthmatic reactions following allergen challenge in mild asthmatics: a randomized, double-blind, placebo-controlled clinical cross-over-trial. Pulm Pharmacol Ther 2006; 19: 233-241.

Krishna MT, Chauhan A, Little L, et al. Inhibition of mast cell tryptase by inhaled APC 366 attenuates allergen-induced late-phase airway obstruction in asthma. J Allergy Clin Immunol 2001; 107: 1039-1045.

Diamant Z, Sidharta PN, Singh D, et al. Setipiprant, a selective CRTH2 antagonist, reduces allergen-induced airway responses in allergic asthmatics. Clin Exp Allergy 2014; 44: 1044-1052.

Fabbri LM, Saetta M, Picotti G, et al. Late asthmatic reactions, airway inflammation and chronic asthma in toluene-diisocyanate-sensitized subjects. Respiration 1991; 58: Suppl. 1, 18-21.

Norris V, Choong L, Tran D, et al. Effect of IVL745, a VLA-4 antagonist, on allergen-induced bronchoconstriction in patients with asthma. J Allergy Clin Immunol 2005; 116: 761-767.

Ravensberg AJ, Luijk B, Westers P, et al. The effect of a single inhaled dose of a VLA-4 antagonist on allergen-induced airway responses and airway inflammation in patients with asthma. Allergy 2006; 61: 1097-1103. Rouhani FN, Meitin CA, Kaler M, et al. Effect of tumor necrosis factor antagonism on allergen-mediated asthmatic airway inflammation. Respir Med 2005; 99: 1175-1182.

0 Gauvreau GM, Boulet LP, Cockcroft DW, et al. Antisense therapy against CCR3 and the common beta chain attenuates allergen-induced eosinophilic responses. Am J Respir Crit Care Med 2008; 177: 952-958.

1 Gauvreau GM, Pageau R, Seguin R, et al. Dose-response effects of TPI ASM8 in asthmatics after allergen. Allergy 2011; 66: 1242-1248. 
142 Gauvreau GM, Hessel EM, Boulet LP, et al. Immunostimulatory sequences regulate interferon-inducible genes but not allergic airway responses. Am J Respir Crit Care Med 2006; 174: 15-20.

143 Richards DB, Bareille P, Lindo EL, et al. Treatment with a peroxisomal proliferator activated receptor gamma agonist has a modest effect in the allergen challenge model in asthma: a randomised controlled trial. Respir Med 2010; 104: 668-674.

144 Luijk B, van den BM, Kerstjens HA, et al. Effect of an inhaled adenosine A2A agonist on the allergen-induced late asthmatic response. Allergy 2008; 63: 75-80.

145 Hoppe M, Harman E, Hendeles L. The effect of inhaled gallopamil, a potent calcium channel blocker, on the late-phase response in subjects with allergic asthma. J Allergy Clin Immunol 1992; 89: 688-695.

146 Nair P, Denis S, Cancelliere L, et al. The effects of an epithelial barrier protective cationic aerosol on allergen-induced airway inflammation in asthma: a randomized, placebo-controlled clinical trial. Clin Exp Allergy 2014; 44: 1200-1203.

147 Duong M, Cockcroft D, Boulet LP, et al. The effect of IVX-0142, a heparin-derived hypersulfated disaccharide, on the allergic airway responses in asthma. Allergy 2008; 63: 1195-1201.

148 Howarth PH, Durham SR, Lee TH, et al. Influence of albuterol, cromolyn sodium and ipratropium bromide on the airway and circulating mediator responses to allergen bronchial provocation in asthma. Am Rev Respir Dis 1985; 132: 986-992.

149 Laube BL, Lin TC, Valleteau A, et al. Allergen challenge and deposition of nedocromil sodium in asthma. J Aerosol Med 2002; 15: 415-425.

150 Kirby JG, Hargreave FE, Cockcroft DW, et al. Effect of indomethacin on allergen-induced asthmatic responses. J Appl Physiol 1989; 66: 578-583.

151 Sestini P, Refini RM, Pieroni MG, et al. Protective effect of inhaled lysine acetylsalicylate on allergen-induced early and late asthmatic reactions. J Allergy Clin Immunol 1997; 100: 71-77.

152 van de Pol MA, Lutter R, Smids BS, et al. Synbiotics reduce allergen-induced T-helper 2 response and improve peak expiratory flow in allergic asthmatics. Allergy 2011; 66: 39-47.

153 Kitz R, Rose MA, Schubert R, et al. Omega-3 polyunsaturated fatty acids and bronchial inflammation in grass pollen allergy after allergen challenge. Respir Med 2010; 104: 1793-1798.

154 Wenzel S, Wilbraham D, Fuller R, et al. Effect of an interleukin-4 variant on late phase asthmatic response to allergen challenge in asthmatic patients: results of two phase 2a studies. Lancet 2007; 370: 1422-1431.

155 Corren J, Lemanske RF, Hanania NA, et al. Lebrikizumab treatment in adults with asthma. N Engl J Med 2011; 365: 1088-1098.

156 Boulet LP, Chapman KR, Cote J, et al. Inhibitory effects of an anti-IgE antibody E25 on allergen-induced early asthmatic response. Am J Respir Crit Care Med 1997; 155: 1835-1840.

157 Pizzichini MM, Kidney JC, Wong BJ, et al. Effect of salmeterol compared with beclomethasone on allergen-induced asthmatic and inflammatory responses. Eur Respir J 1996; 9: 449-455. 